\title{
The Effects of Gamma Irradiation on the Rheology of KTPB Slurries
}

by

D. D. Walker

E. I. du Pont de Nemours and Company

Savannah River Site

Aiken, South Carolina 29808

J. P. Doherty

DOE Contract No.

\section{MASTER}

This paper was prepared in connection with work done under the above contract number with the U. S. Department of Energy. By acceptance of this paper, the publisher and/or recipient acknowledges the U.S. Government's right to retain a nonexclusive, royalty-free license in and to any copyright covering this paper, along with the right to reproduce and to authorize others to reproduce all or part of the copyrighted paper. 


\section{DISCLAIMER}

This report was prepared as an account of work sponsored by an agency of the United States Government. Neither the United States Government nor any agency thereof, nor any of their employees, makes any warranty, express or implied, or assumes any legal liability or responsibility for the accuracy, completeness, or usefulness of any information, apparatus, product, or process disclosed, or represents that its use would not infringe privately owned rights. Reference herein to any specific commercial product, process, or service by trade name, trademark, manufacturer, or otherwise does not necessarily constitute or imply its endorsement, recommendation, or favoring by the United States Government or any agency thereof. The views and opinions of authors expressed herein do not necessarily state or reflect those of the United States Government or any agency thereof.

This report has been reproduced directly from the best available copy.

Available to DOE and DOE contractors from the Office of Scientific and Technical Information, P.O. Box 62, Oak Ridge, TN 37831; prices available from (615) 576-8401.

Available to the public from the National Technical Information Service, U.S. Department of Commerce, 5285 Port Royal Road, Springfield, VA 22161. 


\section{DISCLAIMER}

Portions of this document may be illegible electronic image products. Images are produced from the best available original document. 
$\therefore$ सry

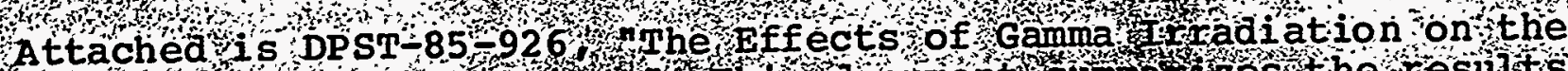

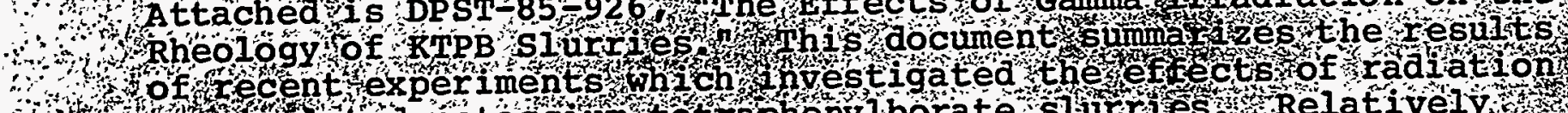

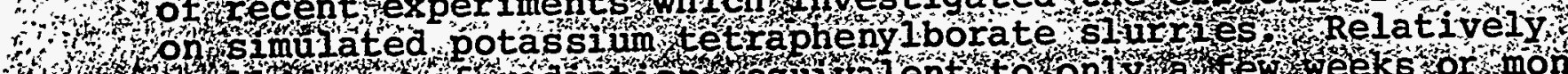

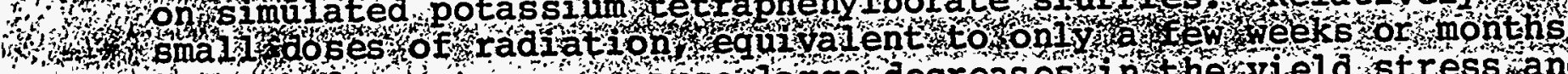

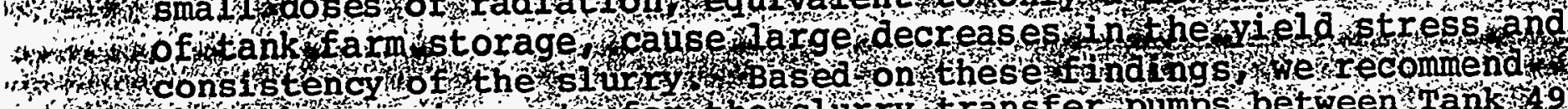

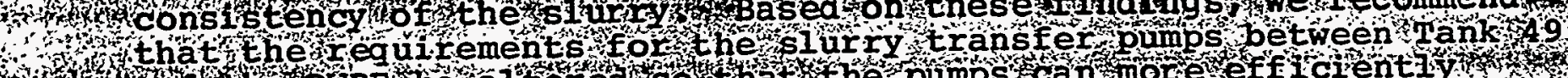

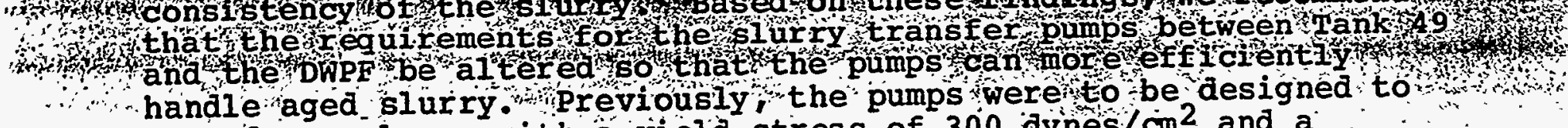
transfer a slurry with a yield stress of 300 dynes/ $\mathrm{cm}^{2}$ and $\mathrm{a}$ consistency of 50 cp. Based on the results documented in this report, the pumps should be designed for a siury of 100 aynes/cm ${ }^{2}$ ana. 30 cp.

DDW : msm

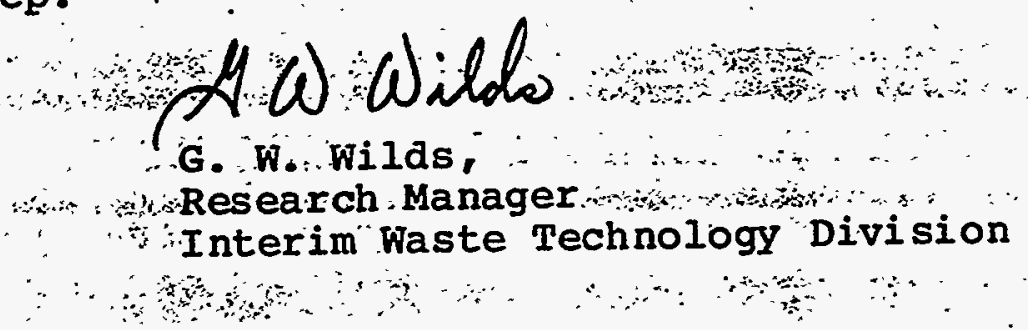

Att

$\# 20$ 


\section{Precipitation process, Rheology, Irradiation effects}

TECHNICAL DIVISION

SAVANNAH RIVER LABORATORY

MEMORANDUM

\author{
DPST-85-926 \\ ACC. No. 189777 \\ CC: G. W. Wilds, 773-A \\ M. D. Boersma (3), 676-T \\ C. T. Randall, 704-T \\ R. E. Eibling, 773-A \\ J. C. Marek, 676-1T \\ M. C. H.. Fong, 676-1T \\ D. T. Hobbs, 773-A \\ MSM File, 773-A \\ SRL File (4), 773-A \\ November 5,1985
}

TO: M. A. EBRA, 773-A<smiles>C1CC[Ge]C1</smiles>

FROM : D. D. WALKER, J. P. DOHERTY

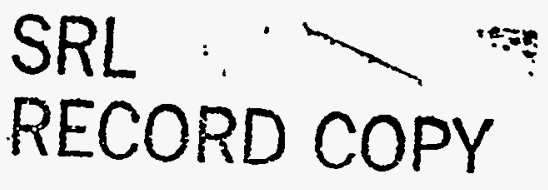

THE EFFECTS OF GAMMA IRRADIATION

ON THE RHEOLOGY OF KTPB SLURRIES

\section{SUMMARY}

Irradiation of the precipitate from the in-tank decontamination process causes dramatic decreases in the yield stress and consistency of the slurry. Experiments using simulated slurries have produced the following results:

- The yield stress of a 10 weight of slurry decreases from 200-300 dynes/ $\mathrm{cm}^{2}$ to less than 10 dynes $/ \mathrm{cm}^{2}$ after an irradiation dose of $4.8 \times 10^{7}$ rads (equivalent to approximately 4 months of tank farm storage).

- The consistency decreases from 30-50 cp to less than $10 \mathrm{cp}$ after the same irradiation dose.

- For a mixture of slurries which have received different radiation doses, the yield stress is approximately equal to the average of the yield stresses of the component slurries. The consistency of a mixture tends to be close to the consistency of the most viscous component.

Based on these results, the pump requirements for transferring this 
slurry from the storage tank to the Salt Processing Cell (SPC) in the Defense Waste Processing Facility (DWPF) can be significantly reduced. The present specifications require that this pump be able to transfer a slurry with a yield stress of 300 dynes/ $\mathrm{cm}^{2}$ and a consistency of $50 \mathrm{cp}$. These requirements can be reduced to 100 dynes $/ \mathrm{cm}^{2}$ and $30 \mathrm{cp}$.

\section{INTRODUCTION}

During the in-tank decontamination process, cesium, potassium and, ammonium ions are precipitated as their insoluble tetraphenylborate salts. Cross-flow filtration separates the liquid from the solids and concentrates the precipitate to a 10 wt 8 solids slurry. After washing to remove soluble salts, the precipitate is stored in a 1.3 million gallon Type III waste tank. The slurry will eventually be transferred to the salt Processing Cell (SPC) of the Defense waste Processing Facility (DWPF) for incorporation of the radioactivity into borosilicate glass.

Initialiy, the precipitate acts like a Bingham plastic fluid with a high yield stress and consistency. To transfer this very thick slurry from the storage taink to the DWPF requires a specially designed pump. However, during the precipitation, filtration, washing, and concentration steps of the in-tank process, the precipitate receives an irradiation dose from the precipitated Cs-137 and the adsorbed Sr-90. Thus, at the time the precipitate is ready to be transferred from the processing tank to the storage tank, it has received a significant radiation dose during the 100 days required for processing. During storage, the precipitate continues to be irradiated as batches are added from in-tank processing and removed to the DWPF. Because of the large inventory of precipitate in the storage tank ( $1.05 \times 10^{6}$ gallons); the average lifetime in the tank is two years. Based on the most recent material balance for the process (Ref. 2), the expected radiation dose is $1.45 \times 10^{8}$ rads/yr (See Appendix A).

The rheological properties of simulated KTPB Slurries (Réf. I) and the precipitate from the full. scale in-tank demonstration (Ref. 3 ) have been measured. For simulated slurries, the yield stress is directly proportional to the concentration of insoluble solids (IS) over the range of concentrations studied ( 4 to $20 \mathrm{wt} \%$ IS for unwashed slurry, 9 to 13 wt o IS for washed slurriest. Yield stresses ranged from 32 dynes/ $\mathrm{cm}^{2}$ for a 4.1 wt \& Is sample to 646 . dynes/ $\mathrm{cm}^{2}$ for a 19.5 wt o Is sample. The consistency was also found to be a linear function of the insoluble solids concentration ( $10 \mathrm{cp}$ for $4.1 \mathrm{wt} \%$.IS, $110 \mathrm{cp}$ for $19.5 \mathrm{wt}$ \& IS). Neither property was affected significantly by the soluble salts in unwashed samples, or by sodium titanate. 
The rheological properties of a slurry sample from the full scale in-tank demonstration were measured despite extreme difficulties in obtaining and handling the material (Ref. 3 ). However, the observed yield stress and consistency of the radioactive slurry were significantly lower than predicted from the work on non-radioactive systems (Table 1). Seven months after the demonstration, a sample of radioactive slurry was concentrated to 12 wt $\&$ solids. The measured yield stress was 72 dynes $/ \mathrm{cm}^{2}$ compared to the expected 340 dynes/ $\mathrm{cm}^{2}$ (based on non-radioactive simulants). Because of the low Cs-137 activity in the salt solution used for the demonstration, the radiation dose received by the slurry during the 7 months of processing and storage only corresponded to a 5 week dose under the anticipated average operating conditions. Based on the results discussed below, this low yield stress can be accounted for by the radiation dose the slurry received.

\section{The Effect of Radiation on Rheological Properties}

To determine the effect of irradiation, simulated 10 wt 8 potassium tetraphenylborate (KTPB) slurries were irradiated in a Co-60 gamma source for the equivalent of up to 2 years of tank farm storage. Radiation doses of 107 rads significantly lowered the yield stress and consistency of the slurries. The results of these tests are listed in Table II and in Figures 1 and 2. The range of radiation doses used were comparable to a 1 month to 2 year storage period in the tank farm. The calculation of the radiation dose is given in Appendix A. As can be seen in Table II, after a dose equivalent to 6 months under tank farm storage conditions the slurry exhibits no. yield stress and behaves similar to water. Most of the decrease occurs during the first $3 \times 10^{7}$ rads of exposure ( 75 days of storage). This is approximately the same time period required to wash the precipitate prior to pumping it to the storage tank. During the washing process, the slurry will contain 9 wt 8 solids and will be subjected to the same irradiation dose that it will received during storage. Thus, it is very likely that fresh slurry going into the storage tank will have a significantly lower yield stress and consistency than predicted from simulated, non-irradiated slurries.

Table II lists results for three aifferent slurry batches. Two of the slurry batches were prepared using an excess of potassium ion during the precipitation, and one batch was prepared using an excess of tetraphenylborate ion (see Appendix B for details of the preparations). It was thought that the method of preparation of the slurry might effect. the initial yield stress and subsequent irradiation effect. However, the two slurries behaved in substantially the same way.

Effect of $\mathrm{pH}$

The pH of the slurry does not to have a significant effect on its 
rheological properties. Two experiments were run: in the first, the $\mathrm{pH}$ of an non-irradiated slurry was adjusted downward using formic acid; and in the second, the $\mathrm{pH}$ of an irradiated slurry was adjusted upward with sodium hydroxide (see Table I). In both cases, the change in $\mathrm{pH}$ had no effect on the, rheological properties. It is known that the $\mathrm{pH}$ of the slurry decreases from an initial value of 12.8 to a low of 9.5 when it is irradiated for the equivalent of three years of tank farm storage (Ref. 4). The pH appears to stabilize at 9.5 due to the buffering action of the decomposition products. It was thought that this change in $\mathrm{pH}$ could have been the cause of the decrease in yield stress and consistency since other systems are known which are $\mathrm{pH}$ sensistive (Ref. 5).

\section{Settling Characteristics and Visual Appearance}

The settling properties of irradiated slurries are considerably different from non-irradiated slurries. A 10 .wt $\&$ slurry has little tendency to settle or compact when allowed to stand. It tends to trap air, which causes foaming, and may also cause the precipitate to float even though the crystals are more dense than water or dilute salt solutions (Ref. 6). The ease with which air is trapped may be due to the hydrophobic nature of the insoluble tetraphenylborate salts. However, after an irradiation dose of $4 \times 10^{7}$ rads ( 0.32 years storage), the slurry slowly settles to approximately 20 wt 8 solids. Longer irradiations do not increase the rate of settling or the final wt solids.

Under microscopic examination, the individual crystals in the slurry appear to be flat plates, from 0.1 to 0.5 microns in thickness and from 0.5 to 5 microns in diameter (Fig. 3 ). The fresh KTPB slurry appears to be composed of agglomerates of the small crystals. The stability of these agglomerates is probably the cause of the high yield stress and viscosity. Irradiation appears to disperse (or de-agglomerate) the original slurry, thereby reducing the yield stress and viscosity. In the irradiated slurry, the agglomerates are smaller and many more individual crystals are present. Based on a limited visual examination, the individual crystals appeared to be the same size and shape after being irradiated.

The mechanism by which irradiation disperses the crystals is not known, but it may be due to the small amounts of decomposition products formed. Two of the major decomposition products (phenol and phenylboric acid) are polar molecules and may be adsorbed on the crystal surfaces, making them less hydrophobic and more hydrophilic. In view of the insensitivity of the rheological properties to ionic strength of the solution (i.e., washed and unwashed slurry), it is unlikely that the high yield stress is caused simply by ionic double layer effects. 


\section{Rheology of Slurry Mixtures}

In the planned tank farm operations, batches of washed slurry will be added to the storage tank approximately every four months. Slurry will be removed from the storage tank in small batches ( 3430 gal) every 43 hours. Therefore, the slurry being removed is a mixture of batches which have received different radiation exposures. The behavior of mixtures was also investigated using the same simulated slurries discussed above. The rheological properties of the mixtures are listed in Table III. The ternary mixture \#3 is an approximate simulation of the contents of the slurry storage tank. The observed yield stresses for mixtures were slightly less than, but very close to, the simple average of the yield stresses of the component parts of the mixture. However, the consistency of the mixtures were, in all cases, much higher than the calculated average. In fact, the consistencies of mixtures were very close to the consistency of the most viscous component.

\section{Effect of Sodium Titanate}

The presence of sodium titanate does not have an effect on the rheological properties of non-irradiated slurries (Ref. 1), nor does its presence significantly affect the changes caused by irradiation. Table IV lists the properties of irradiated slurries which contained 0.4 wt $\&$ sodium titanate. This is the average titanate level expected during full scale operations (Ref. 2). Although the initial slurry has a lower yield stress and higher consistency than other batches of slurry, the percent change in these properties due to irradiation was very similar.

\section{Calculated Rheological Properties for Tank Farm Slurries}

Under anticipated operating conditions for the in-tank precipitation process, a range of rheological properties are expected in the slurry storage tank. The most significant variable in determining the yield stress and consistency of the slurry is the radiation dose it has received. The dose is directly proportional to the cesium level in the slurry, and this is expected to vary significantly from batch to batch. The strontium variations can be neglected because more than 998 of the total radioactivity in the slurry is due to cesium-137. A second consideration is the initial rheological properties of the slurry. In previous tests (Ref. I), the yield stress of simulated slurries have been as high as 250 to 300 dynes $/ \mathrm{cm}^{2}$ with consistencies as high as $50 \mathrm{cp}$. Using the percentage changes in yield stress and consistency reported above, it is possible to calculate expected slurry properties at different cesium levels.

Table $V$ lists the rheological properties expected at different cesium levels using the following assumptions: 
- The initial slurry has a yield stress of 300 dynes/cm ${ }^{2}$ and consistency of $50 \mathrm{cp}$.

- The slurry receives a radiation dose during the 60 days of precipitate washing.

- The storage tank contents can be approximated by a three component mixturè.

- The decrease in yield stress and consistency for a 300 dynes/ $\mathrm{cm}^{2}$ slurry is proportionally the same as for the 210 dynes/ $\mathrm{cm}^{2}$ slurry reported above.

- The yield stress of a mixture is the average of the components, but the consistency is equal to the consistency of the most viscous component.

The average cesium level expected for a 10 wt 8 KTPB slurry is 36 curies/gal. Based on the assumptions above, the expected yield stress of a mixture with this radioactivity level is only 20 dynes/cm ${ }^{2}$ and the expected consistency is $11 \mathrm{cp}$. Even if it is assumed that the slurry is added to the storage tank without receiving a radiation dose, the yield stress would only be 84 dynes/ $\mathrm{cm}^{2}$ and the consistency $50 \mathrm{cp}$. For cesium levels higher than average, the rheological properties of the stored slurry rapidly approach those of water. For lower than average cesium levels, the yield stress and consistency do increase, but do not begin to approach the 300 dynes $/ \mathrm{cm}^{2}$ and $50 \mathrm{cp}$ level even at $28 \%$ of the average expected cesium.

Based on these calculations, it does not seem likely that the pumping system used to transfer the slurry to the DWPF will have to handle a slurry which has a yield stress greater than 100 dynes/ $/ \mathrm{cm}^{2}$ and a consistency greater than $30 \mathrm{cp}$.

\section{EXPERIMENTAL}

The potassium tetraphenylborate slurries were prepared using sodium - tetraphenylborate from the 1983 full scale in-tank demonstration at SRP. The slurries were irradiated in glass containers using the Co-60 source in building $774-A$. The nominal radiation field in the source was $2.98 \times 10^{6} \mathrm{rads} / \mathrm{hr}$ on september 6,1985 . The rheological properties of the slurries were measured using a Haake Rotovisco RV-12 with an M150 measuring drive unit and TI sensor system. The shear stress was measured as the shear rate was varied from 0 to $300 \mathrm{sec}^{-1}$ and back to 0 (using a Haake PG 142 programmer). The shear stress and viscosity of the samples were calculated using a Hewlett-Packard HP 85 computer and the Haake "Rotation" software package. 


\section{QUALITY ASSURANCE}

Quality assurance of the new data reported here is covered by DPSTQA-85-2-25, "Quality Assurance Review: Decontamination of Soluble Defense Waste by In-Tank Precipitation Processing," March 4, 1985, and by DPSTQA-85-2-33, "Quality Assurance Review: Sludge Characterization, "August 15, 1985. The data are recorded in Laboratory Notebook DPSTN -4274 . 
DPST-85-926

M. A. EBRA

\section{References}

1. M. A. McLain and I. D. Goren, "Rheology of Non-radioactive Simulant of Concentrated Tetraphenylborate Precipitate," DPST-84-401, March 30, 1984 .

2. Defense Waste Processing Facility Basic Data Report (Rev. 91), Appendix 1, DPSP-80-827, October 18, 1984.

3. B. A. Hamm, "Rheology of Precipitate from Full Scale In-Tank Demonstration," DPST-83-955, October 28, 1983.

4. D. D. Walker, "Irradiation Effects on the Composition of Potassium Tetraphenylborate Slurries," DPST-85- , to be issued.

5. H. B. Weiser, Inorganic Colloid Chemistry, Vol II, John wiley and Sons, New York, 1935, p 66.

6. J. Ozols, I. Tetere, S. Viba, and A. Ievins, Latv. PSR Zinat. Adad. Vestis, Kim. Ser. 1975, (5), 517-20.

7. E. D. Arnold, "Hanabook of Shielding Requirements and Radiation Characteristics of Isotopic Power Sources for Terrestrial Marine and Space Applications," April 1964, ORNL-3576. 


\section{APPENDIX A}

\section{Calculation of Radiation Dose to the Stored KTPB Slurry}

The potassium tetraphenylborate slurrý which is to be stored in Tank 49 will contain an average of 36 curies of Cs-137 per gallon of slurry (Ref. 2). This includes the 108 of the cesium which is recycled from the melter off-gas system in the DWPF back to the tank farm. The decay energy of $\mathrm{Cs}-137$ is 4.84 watts/kCi (Ref. 7) and includes both the beta (Cs-137) and gamma (Ba-137) contributions. Since cesium-137 comprises more than 998 of the total curie content of the slurry, the decay of other radionuclides can be omitted. It is also assumed that all of the energy of the radioactive decay is deposited within the solution. This is a good assumption for a large tank where the energy deposited in the walls is negligible.

$36 \frac{\mathrm{Ci}}{\mathrm{gaI}} \cdot 4.84 \frac{\text { watts }}{\mathrm{kCI}} \cdot \frac{1 \mathrm{eV} / \mathrm{sec}}{1.6 \times 10^{-19} \text { watts }} \cdot 3.1536 \times 10^{7} \frac{\mathrm{sec}}{\mathrm{Yr}} \cdot$

$\frac{1 \mathrm{gal}}{3,785.4 \mathrm{mI}} \cdot \frac{1 \mathrm{mI}}{1 \mathrm{~g}} \cdot \frac{\mathrm{Irad}}{6.24 \times 10^{13} \mathrm{eV} / \mathrm{g}}=1.45 \times 10^{8} \frac{\mathrm{rads}}{. \mathrm{Yr}}$ 
M. A. EBRA $\quad-10-\quad \because \quad \begin{aligned} & \text { DPST-85-926 } \\ & \text { November 5, } 1985\end{aligned}$

APPENDIX B

Preparation of RTPB Slurries

The 10 wt $\&$ KTPB slurries used for these experiments were prepared by two different methods. Slurries prepared by J. P. Doherty at TNX started with an aqueous solution of potassium salts to which a solution of sodium tetraphenylborate was added. The potassium ion was in excess and sufficient sodium tetraphenylborate was added to produce a 10 wt 8 slurry without a concentration (filtration) step. The slurries prepared by D. D. Walker started with an aqueous solution of NaTPB to which was added a slight deficiency of potassium ion. This method required a filtration step to concentrate the slurry to $10 \mathrm{wt} 8$. A comparison of the final (theoretical) composition is shown in the Table below.

The $\mathrm{K}^{+}$-excess slurry was prepared by dissolving the following chemicals in 168 . pounds of water in a 55 gallon drum: $\mathrm{KNO}_{3}, 2053$ $\mathrm{g} ; \mathrm{KOH}, 788 \mathrm{~g} ; \mathrm{Na}_{2} \mathrm{SO}_{4}, 361 \mathrm{~g} ; \mathrm{K}_{2} \mathrm{CrO}_{4}, 5.9 \mathrm{~g} ; \mathrm{CsNO}_{3}, 139 \mathrm{~g}$; sodium alumi nate $\left(\mathrm{Na}_{2} \mathrm{O} \cdot \mathrm{Al}_{2} \mathrm{O}_{3} \cdot 3 \mathrm{H}_{2} \mathrm{O}\right), 305 \mathrm{~g} ; \mathrm{KNO}_{2}, 627 \mathrm{~g}$; $\mathrm{K}_{2} \mathrm{CO}_{3}, 412 \mathrm{~g} ; \mathrm{K}_{2} \mathrm{HPO}_{4}, 20 \mathrm{~g} ; \mathrm{K}_{2} \mathrm{C}_{2} \mathrm{O}_{4} \cdot \mathrm{H}_{2} \mathrm{O}, 12.1 \mathrm{~g} ;$ and $\mathrm{NH}_{4} \mathrm{OH}(28 \%$ aqueous solution), $75 \mathrm{~g}$. In a second container, 15.25 $\mathrm{kg}$ of NaTPB were dissolved in 168 pounds of water. The NaTPB solution was then pumped into the potassium salt solution while agitating.

The TPB-excess slurry was prepared by dissolving the following chemicals in 4.5 liters of water: $\mathrm{NaNO}_{3}, 11.9 ; \mathrm{NaNO}_{2}, 8.97 \mathrm{~g}$; $\mathrm{NaOH}, 14.4 \mathrm{~g}$; and $97.41 \mathrm{~g} \mathrm{NaTPB}$. In a second container, $28.22 \mathrm{~g}$ $\mathrm{KNO}_{3}$ were dissolved in $500 \mathrm{ml}$ water. The potassium nitrate solution was added slowly with stirring to the tetraphenylborate solution, producing a dilute slurry. The slurry was concentrated to 1.0 liter by filtration. 

M. A. EBRA

\section{TABLE A}

Calculated Composition of RTPB Slurries

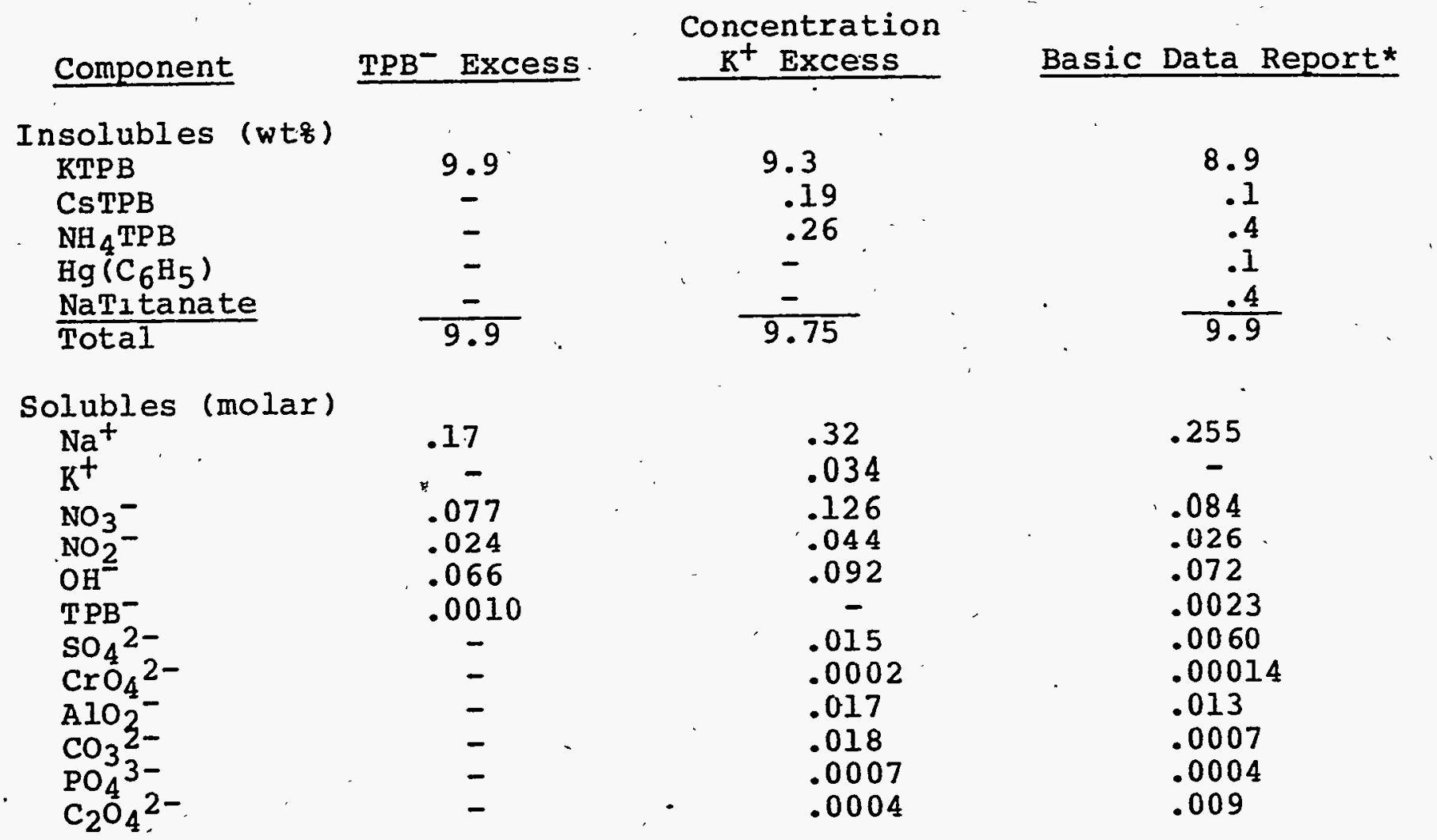

* Ref. 2 . 
TABLE I

Predicted and Observed Properties of Radioactive KTPB Slurries

\begin{tabular}{|c|c|c|c|c|}
\hline & Yield Stress & (aynes $/ \mathrm{cm}^{2}$ ) & Consist & $=y(c p)$ \\
\hline eight \& Insoluble Solic & Predicted* & Observed & Predicted & Observe \\
\hline $\begin{array}{r}7 \\
12\end{array}$ & $\begin{array}{l}154 \\
340\end{array}$ & $72 \pm 34$ & $\begin{array}{l}27 \\
58\end{array}$ & $34 \pm 17$ \\
\hline
\end{tabular}

* Based on Ref. 3.

TAB

Rheological Properties of Irradiated KTPB Slurries

\begin{tabular}{|c|c|c|c|c|}
\hline Sample* & $\begin{array}{c}\begin{array}{c}\text { Radiation Dose } \\
\text { (rads) }\end{array} \\
\end{array}$ & $\begin{array}{c}\text { Equivalent Storage } \\
\text { (years) } \\
\end{array}$ & 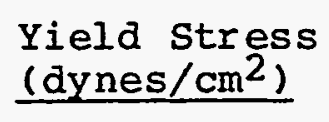 & $\begin{array}{c}\text { Consistency } \\
(\mathrm{cp})\end{array}$ \\
\hline $\begin{array}{l}\text { slurry \#1 } \\
(K+\text { excess })\end{array}$ & \begin{tabular}{ll}
\multicolumn{3}{c}{0} \\
$1.3 \times 107$ \\
$2.4 \times 107$ \\
$4.8 \times 107$ \\
$7.3 \times 107$ \\
$1.5 \times 108$ \\
$2.9 \times 108$
\end{tabular} & $\begin{array}{l}0 \\
0.093 \\
0.17 \\
0.33 \\
0.50 \\
1.03 \\
2.02\end{array}$ & $\begin{array}{r}210 \pm 10 \\
96 \pm 10 \\
42 \\
6 \\
0 \\
0 \\
0\end{array}$ & $\begin{array}{r}26 \pm 3 \\
9 \pm 2 \\
7 \pm 6 \\
5 \\
4 \\
3 \\
3\end{array}$ \\
\hline $\begin{array}{l}\text { Slurry \#2 } \\
\text { ( } \mathrm{R}+\text { excess) }\end{array}$ & $\begin{array}{c}0 \\
2.2 \times 10^{8}\end{array}$ & $\begin{array}{l}0 \\
1.51\end{array}$ & $\begin{aligned} 240 & \left(26^{\circ} \mathrm{C}\right) \\
195 & \left(39^{\circ} \mathrm{C}\right) \\
0 & \left(26^{\circ} \mathrm{C}\right) \\
0 & \left(40^{\circ} \mathrm{C}\right)\end{aligned}$ & $\begin{array}{r}62 \\
36 \\
9 \\
4\end{array}$ \\
\hline $\begin{array}{l}\text { Slurry \#3 } \\
\text { (TPB excess) }\end{array}$ & $\begin{array}{c}0 \\
1.8 \times 10^{7} \\
4.7 \times 10^{7} \\
7.1 \times 107 \\
1.4 \times 10^{8} \\
2.2 \times 10^{8}\end{array}$ & $\begin{array}{ll}0 & (\mathrm{pH}=12.5) \\
0.12 & (\mathrm{pH}=9.1) \\
0.32 & (\mathrm{pH}=11.6) \\
0.49 & (\mathrm{pH}=13.0) \\
0.99 & \\
1.52 & \end{array}$ & $\begin{array}{r}230 \\
270 \\
59 \\
14 \\
13 \pm 10 \\
6 \\
3 \\
1\end{array}$ & $\begin{array}{r}95 \\
170 \\
36 \\
19 \\
11 \pm 4 \\
15 \\
13 \\
16\end{array}$ \\
\hline
\end{tabular}

* See Appendix B for methods of slurry preparation. Slurries \#I and \#2 containe. approximately $9.0-9.3$ wt $\&$ insoluble solids, slurry \#3 contained 9.8 wt 8 KTPB 


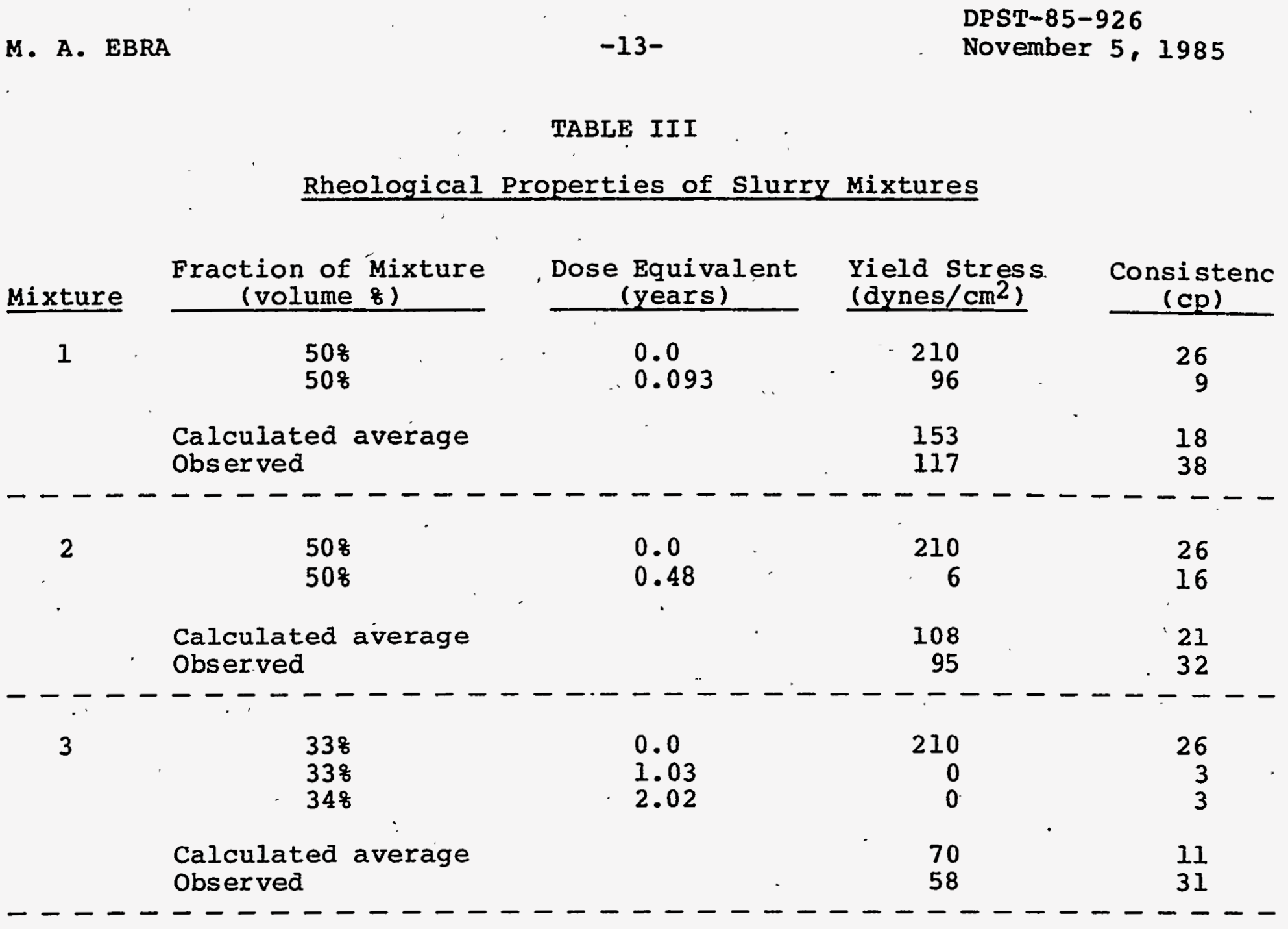

TABLE IV

Rheological Properties of KTPB slurries Containing Sodium Titanate

\section{Radiation Dose (rads)}

0.0 (w/o titanate)

0.0

$1.4 \times 10^{7}$

$6.9 \times 10^{7}$
Equivalent Storage (years)

0.0

0.0

0.094

0.48
Yield Stress (dynes/cm ${ }^{2}$ )

172

177

63

6
Consistency

(cp)

$42^{\circ}$

42

24

16 
TABLE V

\section{Calculated Rheological Properties of KTPB slurries}

Césium level

( $\mathrm{Ci} / \mathrm{gal}$ )

36
Mixture

338 with $0^{-}$years exposure

3.38 with 1 year

338 with 2 years.
Yield Stress

(dynes/cm ${ }^{2}$ )

84
Consistency

(cp)

50

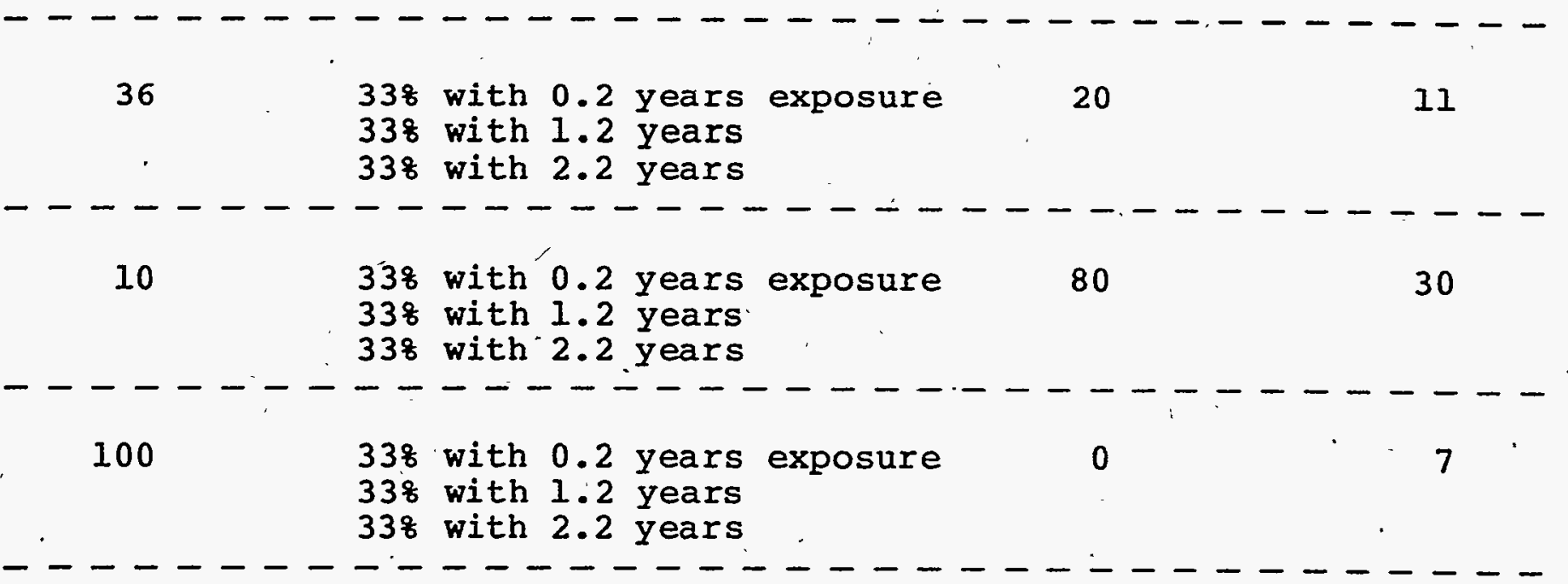




\section{Figure 1}

Yield Stress of Irradiated 10 Wt 8 KIPB Slurries

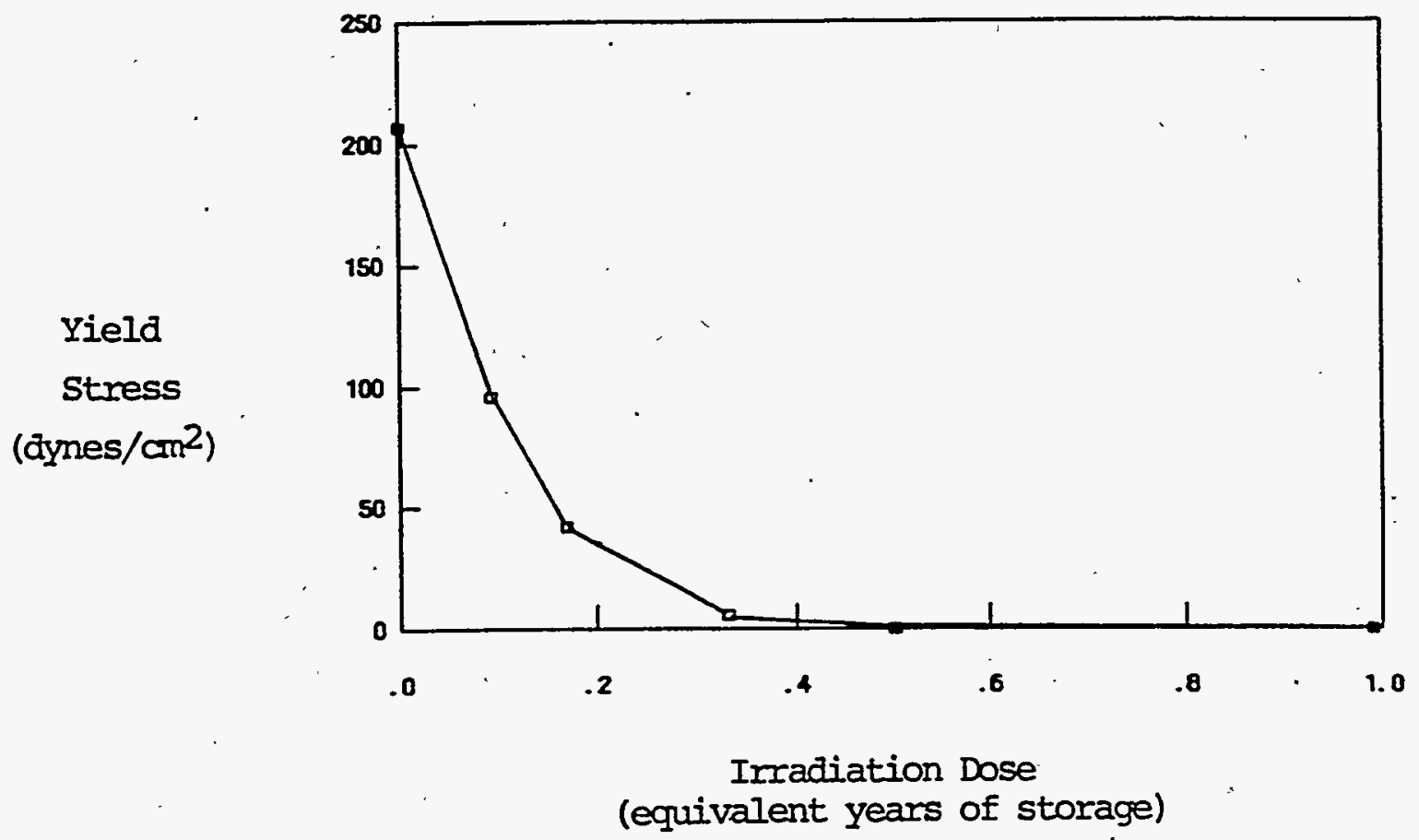

Figure 2

Consistency of Irradiated 10 Wt $\%$ KIPB Slurries

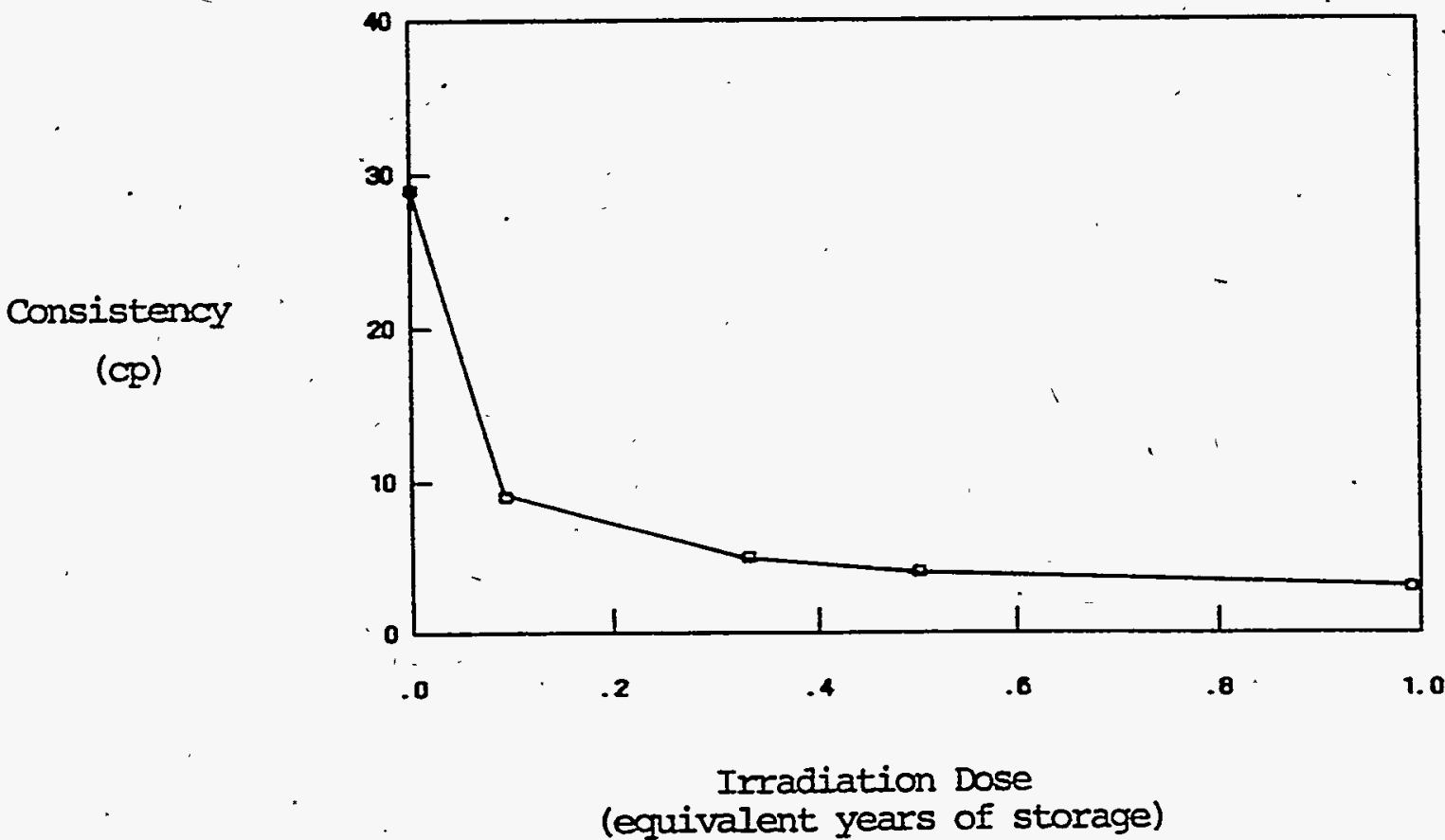




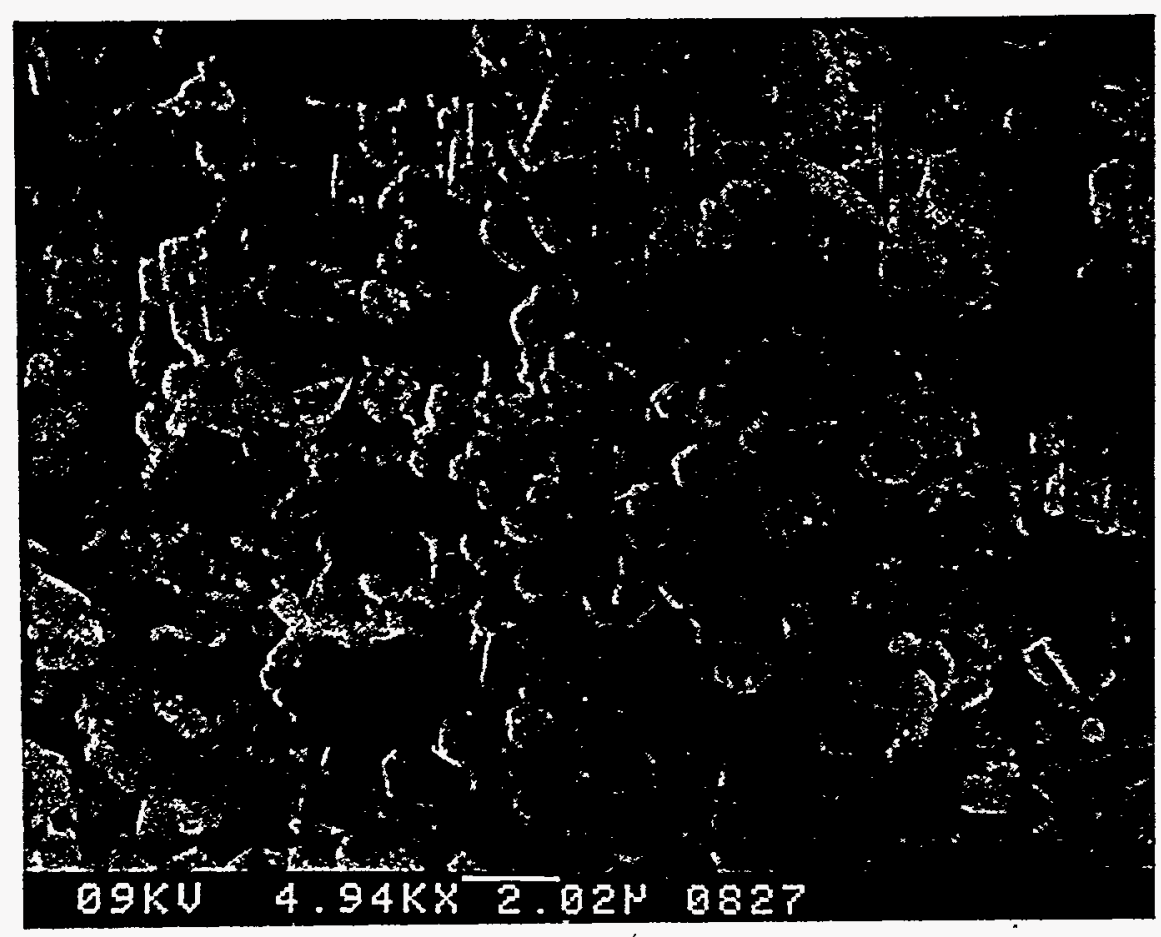

